\title{
The Effect of Various Rootone F Concentrations on Stem Root Stevia (Stevia rebaudiana Bertoni M.)
}

\author{
Diah Ika Putri ${ }^{1}$, Eneng Nurrmuadifah ${ }^{2}$, Lida Amalia ${ }^{3}$, Sri Mulyaningsih ${ }^{4}$, Leni Sri Mulyani ${ }^{5}$ \\ (diahikaputri04@gmail.com¹, nurmuadifaheneng93@gmail.com², lidaamalia@institutpendidikan.ac.id ${ }^{3}$, \\ srimulyaningsih65@gmail.com ${ }^{4}$, lenibiostkip@gmail.com ${ }^{5}$ ) \\ Institute Pendidikan Indonesia (IPI) Garut, Jawa Barat, Indonesia. Jl. Pahlawan No. 32 \\ Sukagalih Tarogong Kidul Garut Jawa Barat, Indonesia ${ }^{1,2,3,4,5}$
}

\begin{abstract}
This study aims to determine and study the effect of various Rootone $\mathrm{F}$ concentrations on the growth of the number and length of the roots of Stevia (Stevia rebaudiana) and to determine the most effective concentration of Rootone $\mathrm{F}$ to stimulate the growth of the roots of Stevia. The benefits of this research are as a way to multiply Stevia plants by utilizing synthetic growth regulators, namely Rootone $\mathrm{F}$ in the pressing process. This research was conducted on May $13^{\text {th }}-$ July $10^{\text {th }}, 2018$ (60 days) and the method used was the experimental method using a Completely Randomized Design (CRD). The number of treatments is five kinds and five repetitions. The treatment of Rootone $\mathrm{F}$ concentration used was $\mathrm{A}=0 \mathrm{ppm}$ (control), $\mathrm{B}=150 \mathrm{ppm}, \mathrm{C}=300 \mathrm{ppm}, \mathrm{D}=$ $450 \mathrm{ppm}$ and $\mathrm{E}=600 \mathrm{ppm}$ with a total sample of 25 polybag of Stevia plants. The results of observations on the growth of Stevia roots both in number and root length showed the highest value in treatment B, namely the concentration of $150 \mathrm{ppm}$. Although statistically it does not show significant differences for both the number and length of roots. From the observations of the data it can be concluded that the Rootone F hormone in a low concentration $(150 \mathrm{ppm})$ stimulates root growth well compared to the greater concentration, it is caused because the hormone which is higher in concentration is an inhibitor of the growth of the roots of stevia plant cuttings.
\end{abstract}

Keywords: Rootone F, Stem Root,Stevia (Stevia rebaundiana Bertoni M.)

\section{Introduction}

The use of synthetic sugar and artificial sweeteners has grown in Indonesia even it has become a habit due to the price of synthetic sugar and artificial sweeteners are much cheaper compared to the price of sugar continues to increase. Whereas the effect of which will result from the use of sweeteners if continuous use will be very harmful to human health. See the impact of the use of synthetic sweeteners, people are starting to switch to using a natural sweetener is one sweetener from the plant Stevia. Stevia rebaudiana Bertonii M is one of the plants sweeteners in addition to sugar cane. This plant-shaped shrubs with a height of about 30 $-90 \mathrm{~cm}$ is derived from the area of Amambay, that is the area of the northeastern part of Paraguay. The leaves of this plant contain a sweetener called europe and rebaudiosida, the level of sweetness is 300 times than sucrose contained in sugarcane crops [1]. The cultivation of Stevia plant in Indonesia is very possible because this plant can grow well in tropical regions. But the problem in cultivation of stevia is which is the multiplication of the stevia plant can be done by seeds, stem cuttings, division of clumps and tissue cultures. Multiplication with cuttings is important to maintain a superior clone easily and simply. The main question in the press is the root. The more roots are formed then the seedlings are increasingly stronger [4]. Among the factors that affect the rooting of one of them is the 
provision of growth regulator substances [4]. Some ZPT used to increase the rooting of cuttings include indole acetic acid (IAA), indole butyric acid (IBA), naphthalene acetic acid (NAA), and Rootone-F. Rootone-F is a synthetic ZPT whose active ingredient is a combination of IBA and NAA which is very effective at stimulating the performance and growth of the cuttings rooting [2]. Based on the explanation above researchers tried to examine how the administration of Rootone $\mathrm{F}$ with varying concentrations of treatment $\mathrm{I}$ with Rootone F 0 ppm as control, treatment II with Rootone F concentration 150 ppm, treatment III with Rootone F Concentration 300 ppm, treatment IV with Rootone F concentration 450 ppm, treatment $\mathrm{V}$ with Rootone $\mathrm{F}$ concentration $600 \mathrm{ppm}$. This treatment is determined by reference in previous research that the effective IBA concentration for the growth of Stevia plant roots is IBA concentration $200-400 \mathrm{ppm}$ [4]. This research has a formulation of problems namely whether there is the influence of administration of various concentrations of Rootone $F$ to the growth of stem cuttings root Stevia (Stevia rebaudiana Bertoni M)?. Further described in some research questions are: 1). How is the influence of the concentration of Rootone F on the growth of stem cuttings roots of Stevia plant (Stevia rebaudiana Bertoni M)? 2). On the concentration of Rootone F What is the most effective in producing the growth of Stevia plant (Stevia reabudiana Bertoni $\mathrm{M}$ )?

\section{Theoritical Review}

\section{A. Description of the Stevia Plant}

Stevia rebaudiana Bertoni $\mathrm{M}$ is a shrub plant originating from the South American region (the border area between Paraguay and Brazil) [1]. Stevia (Stevia rebaudiana Bertoni M.) is an annual plant in the form of shrubs. Its height is $30-90 \mathrm{~cm}$ with a round, stem and green branch. Stevia leaves face each other, ovoid, blunt ends, pointed at the base, flat leaf edges $2-4 \mathrm{~cm}$ long \& $1-5 \mathrm{~cm}$ wide, leaf bones pinnate \& hairy and have short green stems [6] . Stevia's interest is actinomorph, hermaphrodite. The flower crown is tubular. Stevia plants are short-lived plants. This means that the Stevia plant will flower and bear fruit if the length of the day is less than 12 hours. Stevia plants have two root systems, namely fine roots near the surface of the ground and thick roots with thick and rough roots penetrating the soil. Stevia's main products are leaves that are used as raw materials for making sugar or natural sweeteners. Stevia leaves contain stevioside, a glycoside compound that has a sweetness level of $200-300$ times higher than cane sugar or sucrose. Sweetness of cyclamate is 30 times sugar cane [6]. The sweetener in Stevia is low in calories and non carcinogenic [2]. So this plant is known as sugar leaves. The Stevia plant was estimated to enter Indonesia in 1977 with the cooperation of Japanese and Indonesian entrepreneurs. Stevia cultivation has been tried in several areas with an altitude of about 1000 meters above sea level such as in the Tawangmangun, Sukabumi, Garut, Bengkulu, East Java, and South Sulawesi regions [6]. In Indonesia, stevia grows at an altitude between $800-1500 \mathrm{~m}$ asl, air temperature $20-24^{\circ} \mathrm{C}$, rainfall $1500-3000 \mathrm{~mm} /$ year [4]. The type of soil from which the growth originated is terrarosa and latosol, both of which are low in phosphate [1]. In Indonesia, the cultivation of Stevia plants has not been much in demand and is known to many people. This is because not many know the benefits and uses of this plant. Though this plant is very possible to grow in Indonesia because Stevia is a good plant that grows in the tropics. One of the developments carried out was the multiplication of Stevia plants. Stevia can be bred by generative and vegetative methods. Generative propagation of stevia can be done through seeds while propagation of vegetative stevia plants can be done with tillers, stem cuttings and tissue culture. Propagation through cuttings is one of the vegetative propagation of stevia which is 
mostly done by farmers. The advantage of this multiplication is that perfect plants can be produced in a relatively faster time than generatively [2]. By multiplying through cuttings, plant growth is faster and has the same properties as the parent plant. Therefore the selection of the right parent plant is important in this multiplication.

The criteria for quality mother trees are good growth and appearance, derived from healthy mother trees, containing high levels of stevioside. Cuttings are taken from the upper stem of the plant with 5-6 pairs of leaves. In order for root growth to be stimulated, treatment is needed by giving growth regulator substances [2].

\section{B. Substances of Growth and Plant Growth}

In the body of the plant there are plant hormones. Plant hormones are organic compounds that are synthesized in one part of the plant and transferred to another part, and at very low concentrations can cause a physiological response [7]. However, in the body of plants there are only a small amount of organic compounds, so it needs to add hormones from the outside. Synthetic hormones added from outside the plant's body are called Growth Regulating Substances. Regulating Substances Growing which are stimulating growth can accelerate root growth. A concentration that is too high can damage the injured part. The form of damage in the form of cell division and callus is excessive, it can even inhibit the growth of shoots and roots. Meanwhile, if the concentration is lacking, giving hormones becomes ineffective. One of the root growth regulators (ZPT) is Rootone F. Rootone F is one of the traded root growth hormones, in the form of powder, white and useful to accelerate and increase the formation of new roots [5]. The chemical compounds contained in the growth regulator Rootone $\mathrm{F}$ are as follows:

Table 1. Chemical Compounds of Rootone F

\begin{tabular}{ll}
\hline \multicolumn{1}{c}{ Chemical Compounds } & \multicolumn{1}{c}{ Total } \\
1 Naphathalene acetamide & $0.067 \%$ \\
& \\
2 Methyl - 1 - Naphathalene acetic acid & $0.033 \%$ \\
2 Methyl - 1 - Nephathalene acetamide & $0.013 \%$ \\
Indole - 3- Butyriceacid & $0,057 \%$ \\
Thiram & $4.000 \%$ \\
Inert ingredient & 95.330 \\
\hline
\end{tabular}

Three compounds that have Nephathalene function multiply and encourage the emergence of a root. While one active compound containing Indole is useful for multiplying and accelerating rooting, Thiram as a fungicide [3]. Growth means increase in size. Because multicellular organisms grow from the zygote, the increase is not only in volume, but also in weight, number of cells, number of protoplasm, and level of complexity [7]. Plants increase in height and are caused by two things [7], namely: 1). Increasing the number of cells as a result of mitotic division in the meristem at the primary and secondary growth points, 2). Increased cellular components and cell differentiation. Factors that affect growth in plants are distinguished by external factors and factors in [7]. External factors: 1). Food is an energy source and material source for synthesizing various cell components. Nutrients needed by plants are not only carbon dioxide and water, but also other elements, 2). Water is very influential on growth, because plants will not grow and develop without water. Water functions for photosynthesis, activates enzymatic reactions, maintains moisture, and helps 
seed germination, 3). The effect of air humidity varies on various plants. Moist soil and air are good for growth. Humid conditions cause a lot of water to be absorbed by plants and fewer are evaporated, 4). The exposure of light to plant growth is very large through various processes, both because of its intensity, quality, and length of irradiation. Factors in: 1). Genes, in genes contained inherited factors that can be passed on to their offspring. In addition, genes also function to control chemical reactions in cells, such as protein synthesis, 2). Hormones are very essential growth regulators made in one part of a plant. Plant hormones that have been known include auxin, cytokinin, and giberelin.

\section{Method}

The method used in this research is experiment method. The experiment about the influence of various concentration of Rootone $\mathrm{F}$ on the growth of root stem cuttings of Stevia plant (Stevia rebaudiana Bertoni M). The design used in this research is completely Randomized Design (CRD) with five treatments. In this study used five treatments with five repetitions based on the results of the calculation using the formula from Warsa\&Achyar (1982). Treatment given signs A to E, and each sample shows the treatment carried out, namely:

1) Treatment I, namely A1, A2, A3, A4, A5 with 0 ppm treatment

2) Treatment II, namely B1, B2, B3, B4, B5 with $150 \mathrm{ppm}$ treatment

3) Treatment III, namely C1, C2, C3, C4, C5 with a treatment of $300 \mathrm{ppm}$

4) Treatment IV, namely D1, D2, D3, D4, D5 with a treatment of $450 \mathrm{ppm}$

5) Treatment V, namely E1, E2, E3, E4, E5 with 600 ppm treatment

The determination of the layout of the research used the technique of randomising the lottery (or a lottery), the result can be seen in table 2 .

Table 2. Plant Layout Research

\begin{tabular}{lllll}
\hline C3 & A2 & A1 & E1 & C5 \\
B2 & E2 & E5 & D2 & A5 \\
E3 & D3 & B1 & A4 & D1 \\
B3 & B5 & E4 & B4 & D5 \\
C1 & C4 & A3 & C2 \\
\hline & $\begin{array}{l}\text { Explanation : } \\
\text { A - E show treatment } \\
1-5 \text { show repetition }\end{array}$
\end{tabular}

In this study the population used is some of the Stevia plant stem that is obtained from the area of the Cigedug Bayongbong Garut digitally approximate the age of the plant three months (productive plants) with the characteristics of plants that are relatively similar 
and plant height of about $30-45 \mathrm{~cm}$. While the sample used in this study is as much as 50 stem cuttings of Stevia plants obtained from the area of the Cigedug Bayongbong Garut. Sampling based on Simple Random Sampling technique. This research was carried out on May $13^{\text {th }}$ - July $10^{\text {th }}, 2018$ (60 days) in the Laboratory of Department of Biology IPI Garut.

In this research, it takes a few materials and tools as well as supporting the research of, among others, are presented in table 3 and 4 below.

Table 3. List of Tools Used in Research

\begin{tabular}{clcc}
\hline No & \multicolumn{1}{c}{ Tool's Name } & Specification & Total \\
1 & Cut the cuttings & - & 1 \\
2 & Polybag plastic & $\mathrm{d}=15 \mathrm{~cm}$ & 25 \\
3 & Bucket & - & 1 \\
4 & Erlenmeyer & $500 \mathrm{~mL}$ & 2 \\
5 & Plastic hoe & $2 \times 1 \mathrm{~m}$ & 1 \\
6 & Sprayer & - & 1 \\
7 & label & No. 103 & 35 \\
8 & Ruler & $100 \mathrm{~cm}$ & 1 \\
9 & Calculator & Karce & 1 \\
10 & Digital scales & - & 1 \\
11 & Slink psychrometer & - & 1 \\
12 & Ph meter & - & 1 \\
\hline
\end{tabular}

Table 4. List of Materials Used in Research

\begin{tabular}{cllc}
\hline No & \multicolumn{1}{c}{ Materials } & \multicolumn{1}{c}{ Specification } & Total \\
1 & ZPT roots Rootone F & \multicolumn{1}{c}{1,5 gram } & 2 \\
2 & Stevia plant stem & About 5cm long with 5- & 25 plants \\
& $\begin{array}{l}\text { (Stevia reabudiana Bertoni M) } \\
\text { Aquades }\end{array}$ & 6 leaves & $500 \mathrm{ml}$ \\
5 & Soil & $\begin{array}{l}5-10 \mathrm{~cm} \text { depth from the } \\
\text { surface }\end{array}$ & $6 \mathrm{~kg}$ \\
& & Goat manure & $3 \quad \mathrm{~kg}$ \\
\hline
\end{tabular}

The techniques are performed in collecting the data is by way of observation (observation) and measurement systematically to the indicator studied. As for the things that will be observed and measured is the number of roots and root length. The number of roots is calculated at the end of the study by counting the number of roots of each of the cuttings after treatment during the observation, such as watering, cleaning from pests and diseases. Measurement of root length was done by using a ruler that is starting to grow roots from the stem to the tip of the root. This measurement is done at the end of the study. The implementation phase of the research was done through the stages: 1) Preparation Of Growing Media. The Media used for the growth of the cuttings are the soil and manure with a ratio of 2 $: 1$. The soil used for planting media is soil taken at a depth of $5-10 \mathrm{~cm}$ below the surface. A mixture of soil and manure inserted into a polybag and left for 6 days before planting for the 
adjustment of the environment. Retrieval of Material Cuttings Material stem cuttings taken from the stem top with $5-6$ pairs of leaves. The base of the cuttings are cut obliquely and the length of the cuttings about $5 \mathrm{~cm}$. Material cuttings are then soaked with a solution of the fungicide benlate concentration of 1 gram/liter for approximately 5 minutes. It aims to prevent the growth of mold on the material of the cuttings. 2). Preparation of growth Regulators Rootone $\mathrm{F}$. Rootone $\mathrm{F}$ was weighed using digital scales then dissolved in $100 \mathrm{ml}$ of distilled water so that the obtained concentration of the ZPT Rootone F desired. Making the concentration of Rootone $\mathrm{F}$ in the following way:

- The concentration of 0 ppm (without Rootone F)

- Concentration of $150 \mathrm{ppm}$, is $0.15 \mathrm{gr}$ Rootone $\mathrm{F}$ was dissolved in $100 \mathrm{ml}$ of distilled water.

- Concentration of $300 \mathrm{ppm}$, is a mixture of $0.3 \mathrm{gr}$ Rootone $\mathrm{F}$ was dissolved in $100 \mathrm{ml}$ of distilled water.

- Concentration of $450 \mathrm{ppm}$, is a mixture of $0.45 \mathrm{gr}$ Rootone $\mathrm{F}$ was dissolved in $100 \mathrm{ml}$ of distilled water.

- Concentration of $600 \mathrm{ppm}$, is a mixture of $0.6 \mathrm{gr}$ Rootone F was dissolved in $100 \mathrm{ml}$ of distilled water.

3). Administration Of The Hormone. Pieces of cuttings dipped the base into hormone Rootone $\mathrm{F}$ as high as $2 \mathrm{~cm}$ with the concentration according to treatment for $10-15$ minutes.4). Planting Of Cuttings. Cuttings grown on the media that has been prepared. First, made the hole so that the planting of the cuttings are not damaged by rubbing against the ground.Cuttings watered with enough water, then the cuttings closed transparent plastic for 2 weeks. 5). Maintenance. Watering is done 2 times a day, morning and evening to keep the humidity of each of the cuttings.

\section{Results, Discussion and Conclusion}

\section{A. The Results Of The Research}

\section{The calculation for the Number of Roots}

Data on the number of roots after 60 days of observation on each treatment can be seen in Table 5

Table 5. Total of Roots

\begin{tabular}{cccccc}
\hline \multirow{2}{*}{ Repetition } & \multicolumn{5}{c}{ Treatment } \\
& A & B & C & D & E \\
1 & 4 & 6 & 5 & 8 & 8 \\
2 & 2 & 7 & 8 & 8 & 13 \\
3 & 1 & 8 & 11 & 9 & 9 \\
4 & 4 & 9 & 4 & 6 & 16 \\
5 & 4 & 9 & 6 & 7 & 12
\end{tabular}




\begin{tabular}{lccccc} 
Total & 15 & 39 & 34 & 38 & 58 \\
Average & 3 & 7.8 & 6.8 & 7.6 & 11.6 \\
\hline
\end{tabular}

Based on the results of ANOVA test treatment A, B, C, D, and E with $\alpha=0,05$ obtained the value of $F_{\text {count }}(0.15)<$ the value of $F_{\text {table }}(2.87)$, then $H_{0}$ is accepted and $\mathrm{H}_{1}$ is rejected. This means that there is no difference in the influence of various concentration of Rootone $\mathrm{F}$ on the number of roots of Stevia plant (Stevia rebaudiana Bertoni $\mathrm{M}$ ).

\section{The calculation for the Length of the Root}

Data obtained from the results of the study root length after 60 days of observation on each treatment can be seen in table 6 below.

Table 6. Root Length (cm)

\begin{tabular}{|c|c|c|c|c|c|}
\hline Repetition & $\begin{array}{c}\text { Treatment } \\
\text { A }\end{array}$ & $\begin{array}{c}\text { Treatment } \\
\text { B }\end{array}$ & $\begin{array}{c}\text { Treatment } \\
\text { C }\end{array}$ & $\begin{array}{c}\text { Treatment } \\
\text { D }\end{array}$ & $\begin{array}{c}\text { Treatment } \\
\text { E }\end{array}$ \\
\hline & 3.7 & 9.1 & 4.2 & 5.3 & 6.8 \\
\hline & 1.2 & 6.8 & 5.6 & 7.6 & 7.8 \\
\hline & 4.6 & 7.2 & 7.4 & 7.3 & 9.6 \\
\hline & 3.6 & 5.9 & 4.8 & 8.2 & 7.4 \\
\hline 5 & 3 & 7.1 & 5.1 & 6.3 & 8.9 \\
\hline Total & 16.1 & 36.1 & 27.1 & 34.7 & 40.5 \\
\hline Average & 3.22 & 7.22 & 5.42 & 6.94 & 8.1 \\
\hline
\end{tabular}

Based on the results of ANOVA test treatment A, B, C, D, and E with $\alpha=0,05$ obtained the value of $F_{\text {count }}(0.09)<$ the value of $F_{\text {table }}(2.87)$, then $\mathrm{H}_{0}$ is accepted and $\mathrm{H}_{1}$ is rejected. This means that there is no difference in the influence of various concentration of Rootone F on root length of the Stevia plant (Stevia rebaudiana Bertoni M).

\section{B. Discussion and conclusions}

Based on the results of research, observation, and data analysis, it appears the granting of various concentration of Rootone F on the Stevia plant (Stevia rebaudiana Bertoni M) does not cause a real difference to the growth of plants which includes the number of roots and root length. For more details, in figure 1 can be seen the chart the number of roots and length of roots of Stevia plant (Stevia rebaudiana Bertoni M) at various concentration of Rootone F during 60 days of observation. 


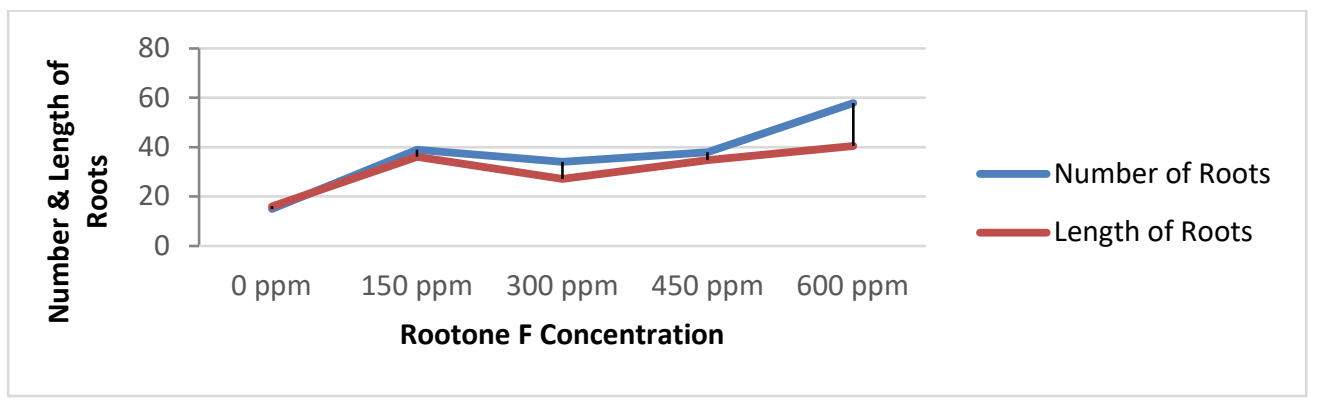

Figure 1. The chart is the Number of Roots and Length of Roots of Stevia (Stevia rebaudiana Bertoni M) during the 60 days

Although the statistical test does not occur the difference in the number and length of roots of plants of Stevia due to the influence of various concentration of Rootone F, but if you see In figure 1 looks the number and length of roots of Stevia plant (Stevia rebaudiana Bertoni $\mathrm{M}$ ) is the most many during the 60 days occurs at the treatment of $600 \mathrm{ppm}$ or treatment $\mathrm{E}$, which means the Stevia plant still respond well to the concentration of the most high. However, in figure 1 shows the treatment of $150 \mathrm{ppm}$ or B has the number and length of roots are high compared with the treatment of $300 \mathrm{ppm}$ and $450 \mathrm{ppm}$, this indicates that the use of growth regulators is most effective for root growth of cuttings of Stevia plants is at a concentration of $150 \mathrm{ppm}$, although the concentration of $600 \mathrm{ppm}$ still produced a state of good growth. While the use of growth regulators in the concentration of high growth in the number of roots and root length appeared more low, it is inexplicable that the hormones of a higher concentration are inhibitors against the growth of roots of cuttings of Stevia plants. This is in accordance with theory which states that the use of growth regulating substances that are stimulating growth can accelerate the growth of roots. Too high a concentration can damage the injured part. The shape of the damage in the form of cell division and callus excessive, it can even inhibit the growth of shoots and roots. Meanwhile, when the concentration is less, the hormone becomes ineffective.[5]

\section{References}

[1] Djajadi. 2014. "Pengembangan Tanaman Pemanis Stevia rebaudiana (Bertoni) di Indonesia". Pusat Penelitian dan Pengembangan Perkebunan. Vol. 13 No. 1 Hlm. 25 -33. http://perkebunan.litbang.pertanian.go.id. Diakses 06 Maret 2016

[2] Indra, Dian. "Empat Teknik Perbanyakan Tanaman Stevia “. Pengawas Benih Tanaman BBPPTP Surabaya. http://itjenbun.pertanian.go.id > gambar > file . Diakses 05 Maret 2016

[3] Kusuma, Agung Surya. 2003. "Pengaruh Zat Pengatur Tumbuh Rootonr - F dan NAA terhadap Keberhasilan Tumbuh Stek Manglid (Magnolia blunei Prantii)". Skripsi. IPB, Jurusan Manajemen Hutan, Fakultas Kehutanan. Institut Pertanian Bogor

[4] Marwani, Lisa . Januari 2011. "Produksi Tanaman Stevia (Stevia rebaudiana Bertoni M) Dengan Perlakuan Stek dan Auksin”. Stevia - USU Institutional Repository. Vol.I No. 01. http:// repository.usu.ac.id > bitstream. Diakses 05 Maret 2016 
[5] M.S., Wijaya dan N.S. Budiana. 2014. Membuat Stek, Cangkok, Sambung, dan Okulasi. Penebar Swadaya : Jakarta.

[6] Rukmana, H. R. 2003. Budidaya Stevia. Kanisius : Jakarta

[7] Salisbury, Frank B \& Cleon W Ross. 1995. Fisiologi Tumbuhan Jilid 3. Trans. Diah R Lukman dan Sumaryono. Bandung: Penerbit ITB

[8] Sundayana, Rostina. 2014. Statistika Penelitian Pendidikan. Alfabeta : Bandung.

\section{Acknowledgements}

The author expresses his greatest gratitude to all those who have helped the author in completing this research, assistance in the form of moral and material support. To the Chancellor of the Institute Pendidikan Indonesia of Garut, Dean of the FITS IPI Garut, Chair of the Biology Education Study Program of IPI Garut and colleagues of the Biology Education Study Program at IPI Garut. This research authors hope to be an additional source of information for the advancement of the field of science. Contribute and benefit in the development of Biology education especially 